\title{
NEO MODERNISME ISLAM INDONESIA: WACANA KEISLAMAN DAN KEBANGSAAN NURCHOLISH MADJID
}

\author{
Suryani \\ Fakultas Ilmu Sosial dan Ilmu Politik UIN Jakarta \\ E-mail: yanisuaeb@yahoo.com
}

\begin{abstract}
Neo modernism emerged as a critical discourse face the phenomenon of modernist Islamic thought that emphasizes reason and ratio in view of the existence of religion in a struggle and debate ideas discourse on Islam and society. In Cak Nur's perspective, a religious leaders is a leading guard for the people who should be able to maintain the originality of religious as well as actualize in society in a more modern ways, to make it interesting for the adherents. In the neo modernism discourse, the phenomenon of religious exclusivity becomes a very important study. The highest truth claims and as the best ways of religiosity in islam already monopolize the disc ourse of truth and salvation or truth and safety. Exclusive theology is used by some hard-line Islamic groups to judge other religions or other Islamic groups that are not inline with Islam that they believe to be the real truth. Neo modernism evolved to respons this religious exclusivity and the religious inclusivity comes to make a new discourse on Islam which has the main idea of an understanding of the universal message delivered by God not only to one particular religion but also to other religions in the scriptures each. The efforts to avoid subjectivity of religion and promote objectivity in the social sphere in Cak Nur's thought will not reduce the religious existence, but will make it more effective and elegant can also be easily accepted by modern society without suspicion.
\end{abstract}

Key words: Islam, Neo Modernism, Rationality, Exclusive Islam, Inclusive Islam

\begin{abstract}
ABSTRAK
Neo-modernisme muncul sebagai diskursus kritis terhadap Islam modernis yang menekankan pada pemikiran dan rasio dalam melihat eksistensi dari agama terkait perjuangan dan perdebatan ide tentang Islam dan masyarakat. Dalam perspektif Cak Nur, pemimpin-pemimpin agama merupakan pelindung warga yang harus mampu mempertahankan orisinalitas dari agama sekaligus mengaktualisasikannya dalam masyarakat dengan cara-cara modern, agar agama menjadi menarik bagi para pengikutnya. Dalam diskursus neo modernisme, fenomena eksklusivitas agama menjadi studi yang sangat penting. Klaim-klaim atas kebenaran tertinggi dan cara-cara relijius terbaik dalam Islam telah memonopoli diskursus kebenaran dan keselamatan. Teologi eksklusif digunakan oleh beberapa kelompok Islam garis keras untuk menghakimi agama lain atau kelompok-kelompok Islam lain yang tidak sejalan dengan ajaran Islam yang mereka yakini sebagai kebenaran sejati. Neo modernisme muncul untuk merespons eksklusivitas relijius tersebut dan inklusivitas relijius lahir untuk membuat diskursus baru dalam Islam yang mempunyai ide utama tentang pemahaman terhadap pesan universal yang disampaikan oleh Tuhan tidak hanya pada satu agama namun juga untuk semua agama dalam kitab sucinya. Upaya untuk menghindari subyektifitas agama dan mempromosikan obyektifitas dalam wilayah sosial dalam pemikiran Cak Nur tidak akan mereduksi eksistensi agama, namun akan membuatnya lebih efektif serta elegan dan juga dapat membuatnya lebih mudah untuk diterima oleh masyarakat modern tanpa kecurigaan.
\end{abstract}

Kata kunci: Islam, neo-modernisme, rasionalitas, Islam eksklusif, Islam inklusif 


\section{PENDAHULUAN}

Para pembaharu agama jelas menolak asumsi bahwa agama adalah titik tertinggi kepasrahan manusia dalam menyikapi kehidupan, sebagai kendaraan dan mekanisme proses mencapai tujuan tujuan kehidupan, seharusnya agama ditempatkan sebagai metodologi yang fleksibel dan bersifat akomodatif dalam setiap persoalan yang muncul, bukan hanya berposisi sebagai pembatas dan pakem yang siap menyalakan rambu-rambu peringatan bila batasan tersebut hampir terlanggar. Agama adalah estetika moral yang menghidupkan manusia bukan hanya untuk menerima kebaikan tetapi juga mentradisikannya dalam prilaku sehari-hari. Risalah kenabian yang membawa pesan - pesan ketuhanan di kemas dalam bingkai agama dan keyakinan yang dihayati secara berbeda oleh setiap pemeluknya, hingga tak jarang, selain sebagai doktrin kebaikan dan pembawa kedamaian, agama seringkali digunakan untuk memantik potensi konflik di tengah masyarakat, juga dijadikan apologi bahkan alibi atas prilaku pemeluknya. Lewat perjuangan dan kekuatan psikologisnya, para nabi berhasil meletakkan dasar-dasar agama yang intinya adalah memanusiakan manusia. Selanjutnya, agama didesain dalam tiga hal penting:

a. Sebagai kata-kata verbal yang berupa kesiapan untuk berkomitmen,

b. Menjadi wadah aktualitas empirik dalam kehidupan,

c. Sebagai bagian dari proses pentradisian kebaikan di masa lalu dan penciptaan kebaikan di masa depan.

Komitmen, realisasi atau aktualisasi serta pentradisian kebaikan adalah kata-kata kunci orang beragama. Tanpa komitmen, cacatlah sebuah agama. Tanpa perealisasian, agama hanya menjadi sebatas iklan. Tanpa pentradisian, agama hanya akan menjadi setumpuk doktrin yang memberatkan. Agama secara psikologis menghadirkan duahal sekaligus; pertama sebagai sumber konvensional yang meliputi kebutuhan rasa aman, respon kekurangan diri, perlunya pengakuan, dan adanya keinginan mendapat pengalaman baru. Sumber kedua adalah sumber modern yang meliputi identifikasi, alat/ideologi pertahanan dan perlawanan. Dua sumber inilah tempat awal dan tempat kembali kehadiran keagamaan dalam masyarakat.
Agama kemudian bertugas melakukan kampanye aktif tentang conscientization atau penyadaran menyeluruh terhadap proses pelestarian menjadi diri manusia sejati. Agama menyadarkan bahwa proses menjadi manusia sejati bukan hanya mengatasi ketergantungan ekonomi, sosial, dan politik. Tetapi juga usaha menuntun manusia untuk mengartikulasikan pembebasan tanpa syarat bagi semua entitas, ras, suku, bahkan jender. Tegasnya, agama adalah perlawanan. Semangat yang di bawa agama adalah motivasi memerdekakan manusia dan memanusiakanmanusia. Sebabkebebasanmanusia; berasal, dari, oleh dan untuk manusia itu sendiri. berasal dari dirinya dan untuk dirinya bukan dari luar dirinya.

Menurut Nurcholish Madjid atau yang akrab di sapa Cak Nur, seorang agama(wan) harusmenjadipalang pintuterakhirumatdanharus mampu menjaga orisinalitas agama sekaligus mengaktualisasikannya dalam kehidupan bermasyarakat secara lebih modern agar mudah di cerna, tidak terkesan basi dan membuatnya terus menarik agar tidak ditinggalkan pemeluknya hanya karena intervensi doktrin yang dimuat agama. Agama pada akhirnya tak lain adalah kejadian-kejadian yang ditulis ulang, diputar ulang dalam rangkaian panjang hingga mampu tampil dengan beragam ekspresi, kompleks, tidak selalu terkesan baik dan hebat. Bagi menjadi seorang muslim yang taat, yang saleh, harus juga menjadi seorang humanis. Seorang muslim harus mempunyai keimanan yang sangat kuat, tapi di saat bersamaan dapat berpikir secara terbuka. Keterbukaan dalam beragama itulah yang akan membuat wajah agama menjadi lebih ramah, egaliter dan realistis. Cak Nur adalah salah seorang pemikir Islam yang mencoba menampilkan titik temu antara ummat, iman, agama, dan bangsa.

Neo modernisme disebut sebagai sebuah gerakan pencerahan atas pencerahan, karena faham ini sangat gigih dalam melakukan kritikan dan gugatan terhadap modernisme yang sangat mendewakan rasio dalam ilmu pengetahuan yang diyakini akan membawa dan mengarahkan manusia memperoleh keselamatan dan kebahagiaan di dalam kehidupannya. Bagi neo modernisme, yang terjadi adalah kondisi sebaliknya dari apa yang diyakini oleh kaum modernis, yakni manusia bukan lagi sebagai subjek dan pelaku untuk memanfaatkan ilmu pengetahuan 
dan teknologi, akan tetapi jatuh terperangkap ke dalam objek dan sasaran yang dikendalikan oleh ilmu pengetahuan dan teknologi itu sendiri. Neo modernisme adalah sebuah fase sejarah yang ingin secara tuntas mengantisipasi dan membebaskan manusia dari segala bentuk cengkeraman zaman yang tak menyenangkan (Norris, 2003:344).

Jika dalam visi modernisme, penalaran (reason) dipercaya sebagai sumber utama ilmu pengetahuan yang menghasilkan kebenarankebenaran universal, maka dalam visi neo modernisme hal itu justru dipandang sebagai alat dominasi, sehingga neo modernisme menyadari bahwa seluruh budaya modernisme yang bersumber pada ilmu pengetahuan dan teknologi pada titik tertentu tidak mampu menjelaskan kriteria dan ukuran epistemologi bahwa yang 'benar' itu adalah yang real, dan yang real benar itu adalah 'rasional'. Meskipun neo modernisme sendiri juga berusaha menggiring manusia ke dalam sebuah paradoks, yaitu di satu pihak telah membuka cakrawala dunia yang serba plural dan universal, yang kaya akan interpretasi dan penafsiran, tetapi di lain pihak, ia menjelma menjadi sebuah dunia yang seakan-akan tanpa terkendali(Pilliang, 2004:358). Neo modernisme bersifat relatif. Kebenaran adalah relatif, kenyataan (realitas) adalah relatif, dan keduanya menjadi konstruk yang tidak bersambungan satu sama lain. Hal tersebut jelas mempunyai implikasi dalam bagaimana kita melihat diri dan mengkonstruk identitas diri. ada banyak macam kebenaran, dan oleh sebab itu tidak ada kebenaran (Roesnou, 1992:31).

Pemahaman agama yang di re-definisi mulai dari yang bersifat tradisional, modern, dan postmodern memunculkan banyak wacana alternative bagaimanamelihat Islam secarainklusif, yang akhirnya memunculkan beberapa aliran seperti Islam Tradisionalis, Islam Fundamentalis, Islam Modernis dan beberapa aliran lain. Aliran aliran yang muncul meniscayakan terbentuknya pengelompokkan dan tipologi gerakan Islam, baik yang bersifat politis maupun yang non politis atau hanya bergerak pada substansi keberagamaan secara vertikal. Kemunculan gerakan dan kelompok yang bersifat politis memberikan warna baru bagi interaksi Islam sebagai agama dan negara sebagai payung kepentingan sosial politik yang lebih besar lagi. Bukan tanpa masalah, tipologi Islam tersebut memunculkan persoalan yang cukup signifikan seperti bagaimana menempatkan Islam sebagai agama Ilahiyah pada pertarungan politik dan kepentingan yang bersifat duniawi.

Bagi para pengusung neo-modernisme, faham ini diharapkan dapat membawa Islam keluar dari alur konvensional yang belakangan justru menampakkan wajah Islam yang negatif baik secara sosial politik maupun secara kultural. Walau mendapatkan counter opini yang cukup banyak, para neo modernis masih menjadikan faham ini sebagai solusi agar Islam bisa tampil dengan wajah yang lebih ramah, rasional tapi tidak melepaskan identitasnya sebagai agama dengan misi keselamatan dan sebagai rahmatan lil'alamin bagi seluruh kehidupan.

\section{KERANGKA KONSEP}

Dalam upaya memahami pemikiran politik Nurcholish Madjid, ada beberapa pemikiran dan pemahaman keIslaman yang dapat digunakan. Diantaranya adalah alur pemikiran neoModernisme yang digagas oleh Fazlur Rahman (1919-1988) seorang tokoh pembaharu Islam asal Pakistan. Konsep neo-modernisme Fazlurrahman berusaha memahami pemikiran pemikiran Islam dan barat secara padu. Karena, bagi Rahman, Islam menyimpan nilai-nilai modernitas jika dipahami secara utuh dan menyeluruh, bukan secara parsial yang justru akan melahirkan sikap eksklusif, jumud, dan intoleran terhadap agama lain. Selanjutnya, Fazlurrahman membagidialektikaperkembangan pembaharuan Islam kedalam empat model gerakan. Pertama, revivalis modernis, yang muncul pada abad ke-18 dan 19, modernism klasik yang muncul pada pertengahan abad 19 dan 20, revivalisme pasca modernis atau neo-fundamentalis dan neo-modernisme itu sendiri. neo modernism Fazlurrhman memiliki karakter utama pengembangan suatu metodologi sistematis dengan melakukan rekonstuksi Islam secara total dan tuntas pada akar-akar spiritualnya dan dapat menjawab kebutuhan Islam modern secara cerdas dan bertanggung jawab (Aziz, 1999:16).

Gagasan neo-modernisme Fazlurrahman di atas kemudian menginspirasi tokoh tokoh pembaharus Islam di Indonesia, diantaranya adalah Nurcholis Madjid yang dikenal sebagai neo-modernis Islam Indonesia bersama Gus Dur. Selanjutnya para penerus pemikiran Nurcholis Madjid seperti Budy Munawar Rahman 
mencoba mengelaborasi pemikiran neomodernisme Islam menjadi tiga tipologi, yaitu Islam rasionalis, Islam Peradaban dan Islam Transformatif (Rahman, 2001:4-7). Tipologi yang dibangun oleh Budy Munawar Rahman dipandang oleh sebagian besar orang sebagai deskripsi atas pluralism Islam yang lebih mendekati kajian tentang Islam liberal.

Kerangka konsep diatas diharapkan dapat membantu menjelaskan bagaimana pemikiran neo modernism Islam Indonesia yang digagas oleh Nurcholis madjid yang menjadi salah satu motor penggerak pembaharuan pemikiran Islam Indonesia menuju rasionalitas Islam sebagai agama pembawa rahmat bagi seluruh alam.

\section{Biografi Intelektual Nurcholish Madjid}

Nurcholish Madjid dengan panggilan akrab Cak Nur, lahir di Jombang, 17 Maret 1939. la dibesarkan di tengah tengah keluarga yang bernafaskan pesantren dan hidup dalam sistem religio feodalisme. Kehidupan pola pesantren yang kuat dalam diri Cak Nur berasal dari ayahnya yang seorang guru pesantren di Tebu Ireng dan juga orang kepercayaan Kyai Hasyim Asyhari, dan ibu seorang putri dari Kyai Abdullah Sajad, pengusaha Industri tebu dan juga salah seorang komisaris Syarekat Dagang Islam.

Pendidikan dasar Cak Nur ditempuh di dua sekolah tingkat dasar, yaitu di Madrasah al-Wathaniyah yang dikelola oleh orang tuanya sendiri, dan di Sekolah Rakyat Mojoanyar Jombang. Sejak kecil Cak Nur memang sudah dibekali dengan dua model pendidikan sekaligus yaitu model pendidikan tradisional dengan kitab kuning sebagai literatur utamanya, dan pendidikan sekolah umum dengan literatur umum dan metode pengajaran modern.

Sebelum menamatkan SR, Cak Nur di kirim ke Pesantren Darul Ulum Rejoso pada tahun 1953 dan berhasil tamat menyelesaikan Madrasah Tsanawiyah pada tahun 1954, lalu meneruskan ke KMI Gontor Ponorogo sampai lulus tahun 1960. Selanjutnya kuliah di IAIN Syarif Hidayatullah Jakarta pada Fakultas Adab Jurusan Sastra Arab sampai lulus sarjana pada tahun 1968, dan melanjutkan di Universitas Chicago pada jurusan Falsafah Islam untuk meraih gelar Doktor berhasil lulus tahun 1984 dengan Disertasi berjudul Ibn Taymiyya on Kalam and Falasifa (Malik, et al., 1998:122).
Sejak kecil, Cak Nur sudah mengalami ketegangan kultural, sang ayah secara kultural berubudiyah NU, tetapi lebih memilih Masyumi sebagai wadah aktivitas politiknya, walaupun pada masa itu NU sudah menjadi partai politik. Ternyatahal tersebutberimplikasipadapergaulan Cak Nur yang sedang belajar di Pondok Pesantren Darul Ulum. Diantara kawan-kawan dan gurunya ia dijuluki anak Masyumi kesasar, akibatnya ia pindah ke KMI Gontor (yang pada saat itu dikenal sebagai pesantren Masyumi). Di situlah Cak Nur menemukan inspirasi tentang modernisme dan non-sekterianisme dalam pemikiran Islam, mungkin karena pola hidup di Gontor yang beda dari kebanyakan pesantren lain, dengan fasilitas dan sistem yang saat itu dinilai modern.

Keinginan untuk maju dan berkembang dalam diri Cak Nur membuatnya selalu aktif dalam setiap kesempatan yang berhubungan dengan pengembangan intelektualisme. Introduksi sistem klasikal yang diterimanya di Rejoso digabungkan dengan sistem modern pesantren Gontor, jadilah perpaduan yang menarik, dan membuatnya kaya akan ide dan pemikiran. Hal tersebut ditunjukkannya ketika ia kuliah di IAIN Jakarta, namanya sebagai intelektuai muda begitu harum, baik dalam organisasi maupun dalam dunia akademis kampus. Cak Nur aktif dalam Himpunan Mahasiswa Islam (HMI), dan menjadi satu-satunya ketua HMI selama dua priode (1966-1968 dan 1968-1970). Namanya cukup terkemuka terutama dalam hal yang hangat dengan persoalan-persoalan gerakan dan keagamaan.

Di dunia Internasional, kiprah tokoh ini cukup besar, ia pemah menjabat sebagai presiden Persatuan Mahasiswa Islam Asia Tenggara (PEMIAT) tahun 1967-1969, wakil sekjen International Islamic Federation of Student Organization (IIFSO), peserta Social Science Research Council (SSRC) New York tahun 1986-1988, peserta Eisenhower Fellowship, Philadelphia tahun 1990, dan anggota Sterring Committee, The Aga Khan Award for Arcitecture, 1992-1995 (Madjid, 1998: 44). Karir Cak Nur dalam dunia internasionai menjadi lebih cemerlang sejak ia diangkat menjadi dosen tamu di Mc Gill University Montreal Canada tahun 1991-1992. Sejak tahun 1992, tokoh ini sudah aktif sebagai pemakalah pada forum-forum internasional, baik dalam materi yang bersifat keislaman maupun pada materi 
umum seperti tentang hak asasi manusia dan civil society, yang selanjutnya menjadi ide brilian yang dikenal dengan masyarakat madani.

Cak Nur muda selalu ingin melahirkan halhal baru dalam wacana intelektualitas Islam. Hal ini dibuktikan dengan usahanya merekonstruksi budaya Barat yang sebelumnya sempat menjadi fenomena yang sangat dicurigainya. Nurcholish Madjid yang pada awalnya anti sekular perlahan berubah, terutama setelah kunjungannya ke Amerika pada tahun 1968. Hal tersebut ditegaskan pada acara halal bihalal organisasi pemuda Islam, ketika menyampaikan makalah berjudul Masalah Integrasi Umat dan Keperluan Pembaharuan Pemikiran Islam. Sejak saat itu julukan "Natsir Muda" yang sebelumnya dilekatkan padanya kehilangan legitimasi. la dipandang oleh sebagian komunitas umat tak layak lagi menyandang gelar itu, selain ternyata ia tak menampakkan diri sebagai kader yang dapat melanjutkan misi perjuangan umat Islam, bahkan ada yang menuduhnya sebagai agen Barat (Trimansyah, 1998:62).

Setelah meraih gelar doktor di Chicago, Cak Nur semakin terkenal sebagai tokoh pembaharu Islam yang gigih, pemikirannya memang tidak mudah dipahami oleh masyarakat ke banyakan, karena pemikiran pembaharuan Islam masih merupakan hal yang langka dan dipandang aneh, Namun demikian, Cak Nur terus menunjukkan kematangan pemikirannya, bahkan ia dikenal sebagai penganjur neomodernisme Islam Indonesia. Hal ini tidak mengherankan karena Cak Nur mengaku sangat dipengaruhi oleh pemikiran Fazlur Rahman, seorang neo-modemisme Islam (Trimansyah, 1998:63).

Sebagai seorang intelektual, Cak Nur termasuk sangat produktif dalam menulis. Hampir setiap tahun ia melahirkan karya-karya, baik dalam bentuk buku maupun tulisan dalam koran dan majalah, dan dapat dipastikan setiap karyanya sangat diminati dan didiskusikan di kelompokkelompok studi, perguruan tinggi, seminar, bahkan juga menjadi obrolan para cendekiawan lain baik secara formal maupun informal. Di antara karyakaryanya yang seringkali dijadikan rujukan dan referensi kajian kajian keislaman adalah:

1. Khazanah Intelektual Islam (1984), buku ini dimaksudkan untuk memperkenalkan salah satu kejayaan pemikiran Islam. Dalam buku ini Cak Nur menyajikan pemikiran-pemikiran
Intelektual Islam klasik seperti al-Kindi, al'Asy'ary, al-Farabi, Ibnu Sina', al-Gazali, Ibnu Rusydi, Ibnu Taimiyah, Ibnu Khaldun, al-Afghani, dan Muhammad Abduh. Buku ini adalah sebuah pengantar kepada kajian intelektual Islam secara lebih mendalam dan lebih luas (Madjid, 1984: vi).

2. Islam Kemoderenan dan Keindonesiaan (1987), buku ini sangat laris hingga dicetak sampai enam kali. Dalam buku ini Cak Nur menuliskan gagasan-gagasannya tentang kemodernan, keislaman dan keindonesiaan.

3. Islam, Doktrin dan Peradaban: Sebuah Telaah Kritis tentang Masalah Keimanan, Kemanusiaan, dan Kemoderenan (1992). Buku ini merupakan kumpulan makalah yang ditulis Cak Nur setelah studi di Chicago. Dalam buku ini diungkapkan tentang konsep Islam yang inklusif serta universalisme Islam dan kemodernan.

4. Islam, Kerakyatan dan Keindonesiaan: Pikiran-Pikiran Nurcholish Muda (1994). Buku ini membahas tentang bagaimana Tauhid bisa menjadi prinsip dalam menciptakan masyarakat yang adil.

5. Pintu-PintuMenujuTuhan(1994).Kumpulan tulisan-tulisan dalam kolom Pelita Hati di koran Pelita sekitar tahun 1981-1991, dan dalam majalah Tempo.

6. Islam Agama Peradaban, Membangun Makna dan Relevansi Doktrin Islam Dalam Sejarah (1995), buku ini merupakan analisa terhadap wacana keislaman dengan lebih mendasar.

7. Islam, Agama Kemanusiaan: Membangun Tradisi dan Visi Baru Islam Indonesia (1995). Menurut Wahyuni Nafis, buku ini memberikan wawasan baru tentang bagaimana membedakan dan memahami mana yang benarbenar mutlak sebagai agama, dan mana yang merupakan budaya dan bersifat sementara.. Karena seringkali terjadi kerancuan dalam membedakan agama dan budaya karena keduanya tidak dapat dipisahkan (Madjid, 1995:21).

8. Masyarakat Religius (1997), berisikan konsep-konsep keluarga Muslim dalam prinsip Islam dan konsep kemasyarakatan.

9. Tradisi Islam: Peran dan Fungsinya dalam Pembangunan Indonesia (1997). Buku ini banyak membahas tentang Pancasila dan demokrasi serta organisasi politik.

10.Kaki Langit Peradaban Islam(1997). Buku ini 
merupakan suntingan sebagian makalah Cak Nur yang ditulis dalam rentang waktu 10 tahun, antara 1986-1996. Berisikan tiga bab. Bab pertama mengetengahkan wawasan peradaban Islam. Bab kedua menjelaskan sumbangan pemikiran para tokoh intelektual Islam seperti AI-Ghazali, Ibn Rusyd, dan Ibn Khaldun. Bab ketiga, baerbicara mengenai dunia Islam dalam dinamika global.

11. Konstektualisasi Doktrin Islam dalam Sejarah (1997). Buku ini tidak hanya memuat tulisan-tulisan Cak Nur, tetapi juga tulisan beberapa tokoh muslim lain. (1997). Dalam buku ini dimuat kegiatan surat-menyurat Cak Nur dengan Mohammad Roem. Mereka berdialog seputar persoalan masa depan politik Indonesia dan tentang konsep Negara Islam.

12.Dialog Keterbukaan: Artikulasi Nilai Islam dalam Wacana Sosial Politik Kontemporer (1998). Buku ini berisikan kumpulan wawancara Cak Nur dengan beberapa media masa seputar persoalan politik, terutama tentang konsep partaioposisiyang selamaini diabaikan oleh kalangan birokrat dan para politisi, Dialog ini membuat Cak Nur tampak sebagai seorang cendikiawan yang menaruh investasi sangat besar pada persoalan kemanusiaan dan demokrasi di Indonesia. Dalam buku ini Cak Nur mengajak ummat Islam untuk menjadi pamong agar bisa mengayomi sesama dengan bersandar pada etika komunikasi yang bijak (Effendy, ed., 1998, hal. xvii).

13. Sajian Rohani: Renungan di Bulan Ramadhan, (1998). Buku ini berisikanan siraman rohani dan arahan-arahan bagi umat Islam tentang konsep dan bagaimana menjalankan puasa dengan baik.

14.Cita-Cita Politik Islam Era Reformasi (1999). Buku terbaru Cak Nur yang merupakan kumpulan tulisan Cak Nur seputar persoalan politik dan usaha reformasi Indonesia, juga terdapat tulisan tentang kekhalifahan dan reformasi bumi yang disampaikan Cak Nur dalam acara pengukuhannya menjadi Guru Besar di IAIN Syarif Hidayatullah Jakarta.

Selain buku-buku yang diterbitkan, Cak Nur juga banyak sekali menulis makalah, artikel, karya tulis baik dalam bahasa Inggris maupun bahasa Indonesia, karya-karyanya banyak menjadi rujukan bagi intelektuai dan cendikiawan Indonesia untuk menyampaikan ceramah maupun untuk melahirkan karya tulis.

\section{Pemikiran Nurcholish Madjid}

Agama yang difahami sebagai pemandu menuju surga seringkali ditempatkan secara sakral tanpa kritik dan cenderung dibiarkan kaku dengan penafsiran yang tidak berkembang. Agama juga ditampilkan di wilayah publik hanya sebatas nilai dan semangatnya, bahkan tak jarang agama dijadikan sebagai kendaraan dan alat politik untuk mencapai kekuasaan dan memuaskan kepentingan, hal ini disebabkan doktrin-doktrin ketuhanan dan klaim kebenaran yang dimiliki agama menjadi eksklusif ketika disampaikan oleh para tokoh yang dianggap sebagai agamawan atau yang dipercayai ummat sebagai orang yang paling mampu menerjemahkan keinginan Tuhan. Seharusnya, pada wilayah publik, agama tidak dimunculkan pada bentuk-bentuk formal. Sebab agama (teis) tidak lah dimaknai sebagai ucapan verbal yang kaku, tetapi lebih pada kelakuan subtansial yang dapat dilihat efektifitas dan karyanya di tengah masyarakat. Dari sini menjadi kurang penting apakah ia beribadat formalis atau tidak. Menjadi kurang penting nama dari suatu agama. Menyikapi perkembangan zaman, hakekat agama adalah hakekat perubahan sejarah, bukan lagi kumpulan dogma, ajaran kaku maupun etika tertutup, melainkan proses-proses historis yang selalu bergerak menuju yang lebih baik, lebih manusiawi dan lebih bisa diterima akal sehat.

Sebagai seorang tokoh pembaharu Islam Indonesia yang berguru langsung pada Fazlur Rahman seorang pencetus neo-modernisme Islam, Nurcholis Madjid mencoba menampilkan wajah Islam Indonesia menjadi lebih ramah, rasional, modern, tapi tanpa mengesampingkan dogma-dogma yang sudah baku diyakini ummat Islam sebagai acuan menuju kesempurnaan di mata Allah. Kemunculan neo modernism dalam Islam menjadi sangat menarik karena para tokohnya bersentuhan langsung dengan pemikiran tradisional Islam dan Modern sekaligus, begitu pula dengan Cak Nur yang mengalami pendidikan perantren tradisional dan dilanjutkan dengan pendidikan pesantren modern, ditambah dengan interaksinya yang intens dengan pemikiranpemikiran Islam klasik dan juga Islam Modernis. 


\section{Faham Keislaman Nurcholish Madjid}

Sebagai seorang yang dibesarkan secara religius, Cak Nur adalah seorang muslim yang taat. Kecintaannya pada Islam ditunjukkan dengan obsesi-obsesinya untuk menjadikan Islam terutama dalam konteks Indonesia sebagai agama yang maju dan mampu menjawab tantangan masa depan. la berusaha menjiwai makna Islam dengan lebih luas lagi. Tekadnya untuk meniupkan angin segar bagi dunia Islam yang menurutnya agak menutup diri dari kemajuan globalisasi dunia membuat Cak Nur banyak sekali mendapat kritikan dan serangan yang tajam dari berbagai kalangan, terutama golongan Islam fundamentalis yang fanatik.

Seperti telah disebutkan di atas, predikatnya sebagai Natsir Muda dengan serta merta lepas karena pemikiran pembaharuannya yang dipandang kontroversial. Pembaharuan bagi Cak Nur adalah sebuah kebutuhan mengingat begitu cepatnya laju globalisasi. Islam tidak bisa tetap bertahan pada pola pikir lama yang pada perjalanannya justru membuat Islam jauh ketinggalan baik secara intelektual maupun teknologi.

Pada tahun 70-an dengan menggunakan teori-teori sosial modernisasiterutama yang di kembangkan Max Weber dan Talcott Parson, Nurcholish Madjid berusaha mengelaborasi ajaran-ajaran Islam (al-Quran dan Sunnah) dan reaktualisasi tradisi Islam itu sendiri (Mujani, 1993: 74-78). Proses ini dilakukan Nurcholish Madjid agar umat menerima kemodernan dalam arti yang sangat luas. Bagi Cak Nur, makna modernisasi berarti merombak pola berfikir dan tata kerja yang tidak akliah dan menggantinya dengan yang akliah, karena Tuhan memerintahkan manusia untuk menggunakan akalnya (Madjid, 1987: 172).Jadi, modernisasi adalah suatu keharusan sejarah, malah kewajiban mutlak. Modernisasi merupakan perintah dan ajaran Tuhan Yang Maha Esa.Ini berarti makna modernisasi telah bermuatan teologis, bukan sekedar kenyataan historis.

Dengan demikian, agenda pemikiran Nurcholish Madjid yang mendasar pada era 70 -an ini adalah bagaimana membawa umat ke alam modern atau dunia kemajuan. Dalam konteks itu pula, wacana pembaharuan pemikiran Islam Nurcholish Madjid sering dikaitkan dengan modernisme dan modemisasi sebagai sebuah fenomena aktual yang sedang dihadapi kaum muslimin kontemporer. Maka, salah satu ciri pembaharuan Nurcholish Madjid pada era 70-an adalah introspeksi atau kritik ke dalam dengan menggunakan metode terapi kejutan (shock teraphy).

Selanjutnya pada masa era 80 -an, fokus pemikiran pembaharuan Cak Nur lebih berkembang lagi dengan berusaha membangun suatu peradaban Islam yang khas dan berakar kuat pada tradisi Islam klasik sebagai langkah strategis untuk memperkaya wawasan intelektual Islam yangbaru. Dalamhal iniCakNursangatapresiatif dengan jargon ulama klasik: "al-Muhafazhat-u 'ala'lqadimi'l-shalih wa'l'akhdz-u bi'l-jadid-l'laslah" (Memelihara yang lama, yang baik, dan mengambil yang baru yang tebih baik) (Madjid, 1999:. xliv).

Pemikiran Cak Nur pada masa itu lebih dipandang sebagai strategi budaya umat Islam untuk membangun peradaban masyarakat modern yang difokuskan pada penggambaran sebuah evolusi alamiah yang mengarah pada proses pematangan intelektuai. Cak Nur sebagai seorang neomodernis berusaha menggabungkan dua faktor penting dalam dunia intetektual yaitu modernisme dan tradisionalisme (Aly dan Effendy,1986, 106). Modernisme Islam menampilkan pemikiran Islam sebagai sesuatu yang tegar, modern, dan kaya dengan ide-ide pembaharuan, sementara tradisionalisme Islam sangat kaya dengan berbagai pemikiran klasik Islam. Faham neo-modernisme Islam lah yang menjembatani dan mengatasi dua pemikiran konvensional di atas.

Menurut M. Dawam Rahardjo, visi mendasar wacana neo-modernisme Islam ini adalah obsesi untuk menjelaskan kaitan antara cita tauhid dan persoalan dunia modern (Rahardjo, 1987:27). Dengan kata lain apa yang diinginkan Cak Nur terutama seperti terlihat dalam tulisantulisannya, adalah aktualisasi iman dalam konteks yang relevan dengan semangat modern.

Pemikiran keislaman Cak Nur yang lain adalah tentang teologi inklusif yang berpijak pada humanitas dan universalitas Islam. Hal ini dimaksudkan sebagai acuan umat menghadapi realitas kemajemukan dan pluralitas yang tidak bisa dihindari. Teologi inklusif memberikan pengertian bahwa Islam adalah agama yang terbuka dan tidak eksklusif apalagi absolut.

Sebagai agama yang menerima pluralisme, Islam diharapkan akan mampu menghadapi 
kehidupan manusia selanjutnya yang akan lebih mudah menemukan konfrontasi langsung antar sesama. Untuk itulah diperlukan sikap saling pengertian dan memahami di antara sesama untuk selanjutnya akan mencari titik kesamaan yang oleh Cak Nur disebut kalimatun sawa (Madjid, 1993: 16). Islam bagi Cak Nur haruslah menjadi agama yang inklusif, adil, manusiawi dan egaliter yang didasari secara sempurna oleh doktrin tauhid. Hal tersebutlah yang akan menjadikan Islam sebagai agama bagi seru sekalian alam.

Sebagai seorang muslim, Cak Nur memiliki cara yang unik dalam menjalankan tugas dakwahnya. la mendirikan Yayasan Wakaf Paramadina, tempat dapat digali pokok-pokok ajaran Islam (termasuk fiqh dan tasawuf) secara lebih modem dan eksklusif, dengan dosen-dosen yang cukup terkenal dan memiliki wawasan Islam yang tidak tradisional dan fundamental. Dalam yayasan Ini Islam bisa tampak sebagai agama yang kontekstual dan tidak kaku.

\section{Faham Kebangsaan Nurcholish Madjid}

Pada kelanjutannya, pemikiran keislaman Cak Nur berkembang menyeluruh masuk ke dalam sendi-sendi kehidupan berbangsa dan bertanah air. Karena dalam visi Cak Nur, berbicara mengenai Indonesia berarti berbicara mengenai Islam Indonesia, hal ini karena Islam adalah agama mayoritas di Indonesia. Pada konsep pluralisme misalnya, sebenarnya konsep tersebut lebih ditujukan sebagai petunjuk hidup bagi bangsa Indonesia yang majemuk dan padat dengan perbedaan, mulai dari suku, bahasa, dan agama.

Kecintaannya pada Indonesia membuat Cak Nur berupaya keras membangun integritas umat dengan bingkai pluralismenya. Bagi Cak Nur, semangat pluralisme dengan prinsip ke manusiaan universal untuk kasus Indonesia sangatlah diuntungkan dengan adanya Pancasila sebagai ideologi terbuka, lepas dari rumusan dan pengkalimatan formalnya seperti dalam pembukaan UUD 1945. Masing-masing nilai dari kelima sila tersebut menciptakan suatu pandangan sosial politik yang potensial sama dan selaras antar semua anggota masyarakat, mengikuti common sense masing-masing pribadi (Madjid, 1999: 186-188). Dalam kehidupan berbangsa, terutama bagi Indonesia yang merupakan negara yang demokratis dengan sistem parlementer, seharusnya rakyat harus diutamakan dalam berbagai pertimbangan, apalagi dengan adanya prinsip kedaulatan rakyat yang merupakan suatu keharusan.

Dalam konteks masyarakat Indonesia, Cak Nur sering menganalogikan Pancasila dengan Konstitusi Madinah (Mitsaq al-Madinah) atau tebih dikenal dengan Piagam Madinah, yang merupakan rumusan tentang kesepakatan-kesepakatan antara kaum Muslim Yastrib (Madinah) dengan berbagai kelompok bukan Muslim untuk membangun masyarakat politik bersama.

Seperti Piagam Madinah, Pancasila juga dipandang sebagai common platform antar berbagai kelompok masyarakat dan agama. Kedudukan serta fungsi Piagam Madinah ini bisa dibandingkan dengan kedudukan dan fungsi Pancasila (Cak Nur tidak ingin menyamakan kedua hal ini). Dalam Piagam Madinah dimuat ide-ide modern politik Islam seperti kebebasan beragama, hak kelompok untuk mengatur hidup dan keyakinannya, kemerdekaan hubungan ekonomi antar gotongan, dan lain-lain. Begitu pula dalam Pancasila yang memuat secara baku aturan-aturan hidup bernegara dan berpolitik bangsa Indonesia.

Menurut Cak Nur, umat Islam Indonesia dapat menerima Pancasila dan UUD 1945 dengan dua pertimbangan: pertama, nilai-nilainya dibenarkan oleh ajaran agama Islam. Kedua, fungsinya sebagai nuktah-nuktah kesepakatan antar berbagai gdongan untuk mewujudkan kesatuan politik bersama (Madjid, 1999: 5658). Untuk menjadi sebuah sumber etika politik yang mantap, Pancasiia harus melalui proses peragian dengan berbagai sumber hukum lain. Lebih lanjut Cak Nur mengatakan dalam suratmenyuratnya dengan Mohammad Roem:

Ada sumber-sumber pandangan etis yang meluas dan dominan, yang secara sangat potensial bisa menjadi ragi pandangan etis bangsa secara keseluruhan, dan yang bisa dijadikan bahan pengisian wadah etika Pancasila. Yaitu pertama, etika kebangsaan Indonesia yang perwujudan paling baiknya dan penampakan paling dinamis-nya ialah Bangsa Indonesia. Kedua, Etika kemodernan yang merupakan akibat langsung keberadaan kita di abad modern..Ketiga, etika Islam yang sebagai anutan rakyat merupakan agama paling luas menyebar di seluruh tanah air dan peranannya diakui para ahli sebagai perata jalan untuk 
tumbuhnya paham-paham maju dan moderen di kalangan rakyat kita, khususnya dalam bentuk paham persamaan manusia (egalitarianisme) dan pengakuan serta penghargaan kepada adanya hak-hak pribadi, selain paham hidup rnenurut aturan atau hukum (pengaruh langsung sistem Syari'ah), weltanshauung yang lebih bebas dari tahayyul (Madjid dan Roem, 1997: 75).

Bila Pancasila dapat menjadi sumber terpenting hukum Indonesia seperti Piagam Madinah menjadi sumber dan dasar-dasar hukum politik Islam, maka persoalan dan masalahmasalah politik yang sekarang sedang menyelimuti Indonesia akan menjadi lebih mudah diselesaikan, karena lebih tergantung pada mental-mental para politisi dalam menjalankan perundang-undangan yang sudah ada, walau undang-undang tersebut masih perlu diperbaiki dalam beberapa hal. Yang harus diantisipasi daiam pelaksanaan Pancasila adalah pengkhianatan-pengkhianatan yang mungkin saja muncul di kalangan masyarakat khususnya para penyelenggara pemerintahan, seperti pengkhianatan atas Piagam Madinah yang dilakukan oteh kaum Yahudi.

Sekalipun ada ketegangan yang muncul berkaitan dengan Islam dan Pancasila, hal itu jangan dilihat sebagai pertentangan (hal ini kerapkaliterjadikarenaIslamadalahmayoritas), tetapi lebih jauh jalan keluar dari masalah tersebut harus dicari secara pragmatis dengan melihat akar permasalahannya. Menurut Cak Nur hal tersebut sering disepelekan, karena umumnya budaya politik Indonesia menilai sebuah persoalan yang menyinggung agama dari unsur SARA (Suku, Agama, Ras, dan antar Golongan).

Kecendrungan untuk secara gampang mencari keterangan atas suatu kesulitan sosialpolitik yang datang dari suatu kelompok yang stereoptipikal mengaitkannya kepada hal-hal yang prinsipil seperti Pancasila dan UUD 1945 adalah menunjukkan suatu cara berpikir yang terlalu sederhana dan ketakutan dalam menghadapi persoalan, dan mungkin juga karena menghendaki keuntungan politis dari persoalan tersebut, akibatnya tidak akan pemah dapat ditemukan penyelesaiannya secara tuntas (Madjid, 1999: 65).

Bagaimanapun besamya perbedaan cara hidup masyarakat Indonesia, bagi Cak Nur tetap harus berada dalam satu model tatanan ideal yaitu masyarakat madani di Indonesia. Untuk meresapi ajaran Islam tidak perlu berada dalam negara Islam, tetapi cukup dengan mewujudkan masyarakat Islam. Pada pemikiran inilah akan tampak Islam yang universal sebagai sebuah agama yang dibutuhkan oleh masyarakat Indonesia yang majemuk dan sedang dalam proses modernisasi dalam bidang sosial, politik, dan ekonomi.

Pancasila akan tampak sangat Islami bila dilihat dan dihayati dengan sudut pandang Islam. Lebih lanjut Cak Nur mengatakan: "Karena itu, kini bangsa Indonesia sangat comportable dengan gagasan mereka berkenaan dengan hubungan antara agama dan negara yang didasarkan pada Pancasila sebagai titik temu antara seluruh golongan. Demikian fakta ini memperlihatkan dan kita yakin, bahwa segala sesuatu berada dalam proses menjadi." (Madjid, 1995: 21).

Pandangan Cak Nur tersebut dengan jelas menunjukkan bahwa baginya negara Pancasila telah menunjukkan suatu bentuk yang valid dan final untuk Indonesia. Jadi, tidak perlu pusing memikirkan bentuk negara Islam secara formal. Yang terpenting adalah bagaimana masyarakat Indonesia dan seluruh aparat pemerintahan mampu mewujudkan relevansi antara ajaran Islam dan Pancasila itu sendiri. Jangan mengkambinghitamkan Pancasila dalam kasus krisis kepercayaan yang sekarang sedang menimpa Indonesia. Yang terpenting sekarang adalah, mewaspadai munculnya pengkhianatpengkhianat Pancasila seperti dulu terj'adi pengkhianatan atas Piagam Madinah oteh kaum Yahudi.

\section{Neo-Modernisme Islam Dalam Perspektif Nurcholish Madjid}

Ada keterkaitan yang tidak bisa dilepaskan antara wacana neo modernism dan pemahaman mengenai pluralism agama, dua hal ini adalah materi pokok yang tidak bisa ditinggalkan saat membahas Islam kekinian dan kontribusinya bagi kemanusiaan secara lebih luas. Ada empat pemahaman mengenai pluralisme agama jika dihubungkan dengan kebenaran agama yang menimbulkan klaim kebenaran: pertama, tidak setiap agama memiliki kebenaran karena kebenaran mutlak hanya pada satu agama. Kedua, kebenaran ada pada setiap agama, tapi kebenaran mutlak hanya ada pada satu agama. Ketiga, kebenaran itu ada pada semua agama secara 
menyeluruh. Keempat, sekalipun kebenaran ada pada masing-masing agama tetapi, pada akhirnya akan menuju pada kebenaran tunggal. Sementara dari ke empat pemaham di atas yang berkembang di tengah masyrakat adalah pemahaman yang lebih superior-inferior tentang kebenaran agama sehingga truth claim tidak bisa dihindarkan. Neo-modernisme Islam memiliki pandangan bahwa klaim kebenaran hanyalah sebuah ajaran teologi yang perlu mendapat interpretasi ulang. Tidak ada kebenaran mutlak, sebab kebenaran tunggal hanya ada pada Tuhan. Hal ini didasarkan pada pandangan Islam bahwa Islam merupakan agama universal dan fitrah yang memuliakan manusia (Qodir, 2006: 91).

Pandangan Cak Nur terhadap pluralisme dan toleransi di dasarkan pada kebenaran ajaran kitab suci dan pengalam tradisi klasik Islam, dimana ada kaum minoritas dan mereka bebas dalammelakukanibadahsepertiyang dikehendaki agamanya. Selain itu, Islam merupakan agama universal, tidak hanya untuk satu golongan. Hal ini, menurut Cak Nur dapat dilihat dari kata Islam itu sendiri, yaitu sikap tulus dan pasrah kepada Tuhan Yang Maha Esa. Islam juga bukan lah agama yang berdiri sendiri. Melainkan, ia tampil dalam rangkain agama-agama lainnya yang telah berdiri terlebih dahulu (Aziz, 1999: 51).

Pluralisme yang terbentuk dari keragaman pemahaman tentang Islam membuat universalitas Islam semakin menguat, tanpa menolak faktor-faktor lokal yang sudah terinternalisasi dalam memahami Islam sebagai sebuah ajaran vertikal, Cak Nur memandang Islam yang dimaknai pasrah tidak tumbuh karena paksaan tapi dalam koridor keterbukaan yang secara teologis harus dibungkus dalam kaidah keikhlasan. Bila sudah didudukkan sebagai ajaran yang terbuka, Islam juga bisa berinteraksi secara bebas dengan sector kehidupan yang lain, seperti politik, baik yang bersifat local maupun yang internasional. Universalitas Islam dimaksudkan untuk menghindari munculnya dominasi dan monopoli keutamaan beragama.

Dalam kontek pemikiran sosial-politik, sikap pemikir noe-modernis yang akomodatif terhadap pemikiran modernis dan tradisionalis berpengaruh terhadap cara pandang kaum modernis dalam melihat hubungan Islam dan Negara (Ali dan Effendy, 1986: 177). Pembaharuan Nurcholis Madjid merupakan penjelasan lebih halus dari konsep kesesuaian islam dan modernisasi sosio-politik Indonesia kontemporer. Dalam hal ini Cak Nur merujuk pada konstutusi Madinah sebagai contoh dasar keislaman, dimana, ia merupakan dokumen politik pertama dalam sejarah islam yang diperlukan oleh masyarakat madinah pada waktu itu. "Islam Yes, partai Islam No" demikian salah satu ungkapan Norcholis Madjid. Menurutnya, bahwa tidak ada Negara Islam. pemikiran neomodernisme hendak mendamaikan atau menempatkan hubungan harmonis antara cita-cita Islam dan Negara (Ali dan Effendy, 1986: 181).

Dalam kaitannya dengan demokrasi, Cak Nur menganggap bahwa tak ada pertentangan antara Islam dan demokrasi walau, mencari kaitan antara keduanya tidak terlalu mudah. Di sisi lain, sebagaimana pandangan ulama dan penguasa politik, bahwa dalam islam tak ada tempat untuk demokrasi. Alasan mereka adalah bahwa demokrasi adalah kekuasaan di tangan rakyat. Sementara dalam doktrin Islam kekuasaan mutlak berpusat pada kekuasaan tuhan (Aziz, 1999: 64).

Oleh karena itu, Islam dan demokrasi, bagi kalangan neo-modernis, ditafsirkan sebagai sesuatu yang sesuai, tidak ada benturan- dalam arti asalnya. Cak Nur berpendapat, salah satu nilai demokrasi adalah egaliter: persamaan. Prinsip egaliter ini adalah prinsip yang terdapat dalam islam. Egalitarianisme dalam islam di sini, ialah adanya kesamaan, keadilan, eksistensi dan demokrasi, prinsip-prinsip musyawarah, perwakilan dan partisipasi, termasuk keadilan hukum yang telah diteapkan sejak zaman Nabi (Qodir, 2006: 84). Analisis Cak Nur berdasarkan kepada ayat-ayat al Qur'an, seperti tentang tanggung jawab, musyawarah, keadilan dan lainnnya sampai kepada sebuah kesimpulan bahwa Islam sepanjang ajaran agamanya, tidak menghendaki sesuatu kecuali demi kebaikan bersama.

Melangkah lebih jauh ke dalam pembahasan neo modernism Islam di Indonesia, sifat inklusif dan eksklusifitas Islam Indonesia menjadi hal yang penting juga untuk di kaji, dua wacana tersebut adalah kelanjutan pemikiran neo modernism yang berkembang pada wilayah yang lebih spesifik, yaitu pada wilayah teologi (Madjid, 1986: 99). Klaim kebenaran tertinggi dan sebagai yang paling baik yang selama ini dilakukan oleh Islam sudah memonopoli wacana truth and salvation atau kebenaran dan 
keselamatan sehingga memposisikan agama lain sebagai yang tidak benar dan bukan yang terbaik. Teologi eksklusif ini seperti memberi wewenang bagi Islam untuk menghakimi agama lain. Menyikapi eksklusifitas agama (yang sebenarnya tidak hanya dilakukan oleh Islam, tetapi juga oleh agama lain yang menggunakan standar kebenaran secara subyektif) muncullah wacana tentang inklusifitas Islam yang memiliki ide utama pemahaman mengenai pesan universal yang disampaikan oleh Tuhan tidak hanya pada satu agama tertentu tetapi juga kepada agama lain dalam kitab sucinya masing masing (Al-Qur'an, Injil, zabur dan Taurat), hal ini ditegaskan oleh Cak Nur:

Pesan itu bersifat universal dan merupakan kesatuan esensial semua agama samawi, yang mewarisi abrahamic religion, yakni yahudi (Nabi Musa), Kristen (Nabi Isa), dan Islam (Nabi Muhammmad). Lewat firmanNya Tuhan menekankan agar kita berpegang teguh kepada agama itu, karena hakikat dasar agama-agama itu sebagai pesan Tuhan adalah satudan sama. Agama Tuhan, pada esensisnya sama, baik yang diberikan kepada Nabi Nuh, Musa, Isa, atau kepada Nabi Muhammad (Madjid, 1992: 226).

PendapatCakNurdiatasmendapatbanyak kritik pedas dari para ulama dan pengikut Islam Tradisional yang masih memandang Islam sebagai al islamu ya'lu walayu'a alaih atau Islam itu yang paling tinggi dan tidak ada yang lebih tinggi darinya. Dengan merujuk pada Ibnu Taymiyah Cak Nur menguatkan wacana inklusifitas Islamnya dengan memaknai istilah "sama" dalam memandang seluruh agama terletak pada pemahaman tentang paham ke tuhanan yang Monotheis yang dalam Islam difahami sebagai Tauhid.

\section{PENUTUP}

Nurcholis Madjid memang bukan satu satunya tokoh pembaharu atau neo modernism Islam Indonesia, masih ada tokoh seperti Abdurahman Wahid yang pemikiran keIslamannya juga dianggap "tidak biasa" oleh common sense karena seringkali memunculkan kontroversi baik pada tingkat wacana maupun pada praktek keagamaan yang dilakukan. Masih banyak para pemikir muda yang mengikuti jejak pemikiran Cak Nur dan Gus Dur, hanya saja klaim public yang menyamakan paham neo modernism dengan islam sekuler atau Islam Liberal membuat pemikiran tentang neo modernism seperti tidak menemukan anti klimaks nya. Ditambah lagi dengan makin maraknya bermunculan kelompok Islam tradisionalyang dibungkus dengan gerakan radikal dan menguatkan wacana eksklusifitas Islam sebagai satu satunya agama yang berhak atas kebenaran dan memonopoli Tuhan sebagai hak mereka saja. Para pembaharu agama pasca Cak Nur punya pekerjaan berat yang sangat menantang menghadapi publik yang makin rumit, negara yang tidak akomodatif, para ulama yang mempolitisir agama, Karena itu, mulai sekarang akan sangat baik bila para pembaharu kembali meneguhkan niat baiknya untuk mengkaji lebih dalam dan mentradisikan pesan-pesan agama yang universal agar publik menjadi terbuka, demi mengurangi gesekan dan konflik keberagamaan yang belakangan ini makin mengkhawatirkan.

\section{DAFTAR BACAAN}

Ali, Fachry dan Bachtiar Effendy. 1986. Merambah Jalan baru Islam: Rekonstruksi Pemikiran Islam Masa Orde baru, Bandung: Mizan.

Aziz, Ahmad Amir. 1999. Neo Modernisme Islam di Indonesia, Jakarta: Rineka Cipta.

Effendy,EdyA.(ed.).1998. Dialog Keterbukaan, Artikulasi Nilai islam Dalam Wacana Sosial Politik Kontemporer, Jakarta: Paramadina.

Madjid, Nurcholish (ed.). 1984. Khazanah Intelektual Islam, Jakarta: Bulan Bintang,

dan Mohammad Roem. 1997. Tidak Ada Negara Islam, Surat-Surat Politik Nurcholish Madjid-Mohammad Roem, Jakarta: Penerbit Djambatan.

1993. Beberapa Renungan Tentang Kehidupan Keagamaan Untuk Generasi Mendatang, Jurnal Ulumul Qur'an no. 1 vol. iv.

1999. Cita-Cita Politik Islam Era Reformasi, Jakarta: Paramadina. 
-, 1995. Islam Agama Kemanusiaan, Jakarta: Paramadina.

1992. Islam Doktrin dan Peradaban, Jakarta: Paramadina.

1987. Islam Kemoderenan dan Keindonesiaan, Bandung; Mizan.

1998. Kalam Kekhalifahan Manusia dan Reformasi Bumi, Pidato Pengukuhan Guru Besar Luar Biasa Dalam Bidang Ilmu Filsafat Islam IAIN Jakarta, 1998.

Malik, Dedy Djamaluddin, et-al., 1998. Zaman Baru Islam Indonesia: Pemikiran dan Aksi Politik Abdurrahman Wahid, M.Amin Rais, Nurcholish Madjid dan Jalaluddin Rakhmat, Bandung:Zaman Wacana Mulia.

Mujani, Saiful. 1993. Islam dalam Hegemoni Teori Modernisasi:Telaah kasus Awal, dalam Jurnal Prisma no.1.

Norris, Christopher, 2003., Membongkar teori dekonstruksi Jaques Derrida, Terjemahan. Inyiak Ridwan Muzir. Ar-Ruzz: Yogyakarta.
Pilliang, Amir Yasraf, 2004., Posrealitas: Realitas kebudayaan dalam era posme tafisika. Jalasutra: Yogyakarta.

Qodir, Zuli, 2006., Pembaharuan Pemikiran Islam, Wacana Dan Aksi Islam di Indonesia, Yogyakarta: Pustaka Pelajar.

Rahman, Budhy Munawar, 2001. Islam pliralis Wacana Kesetaraan Kaum Beriman, Jakarta: Paramadina.

Rizem's Archives' blog, Neomodernisme Menuju Islam Modernis.htm, mengutip Abdul A'la Al-Maududi dalam bukunya "Dari Neomodernisme ke Islam Liberal, Jejak Fazlur Rahman Dalam Wacana Islam di Indonesia"

Rousnou, Pauline Marie, 1992.,Post-modernism and the social science: Insights inroads, and intrusions. Rinceton University Press: Priceton.

Trimansyah, Bambang, 1998., Merintis Jalan Kritis, Bandung: Zaman Wacana Mulia. 